\title{
Peran Dan Strategi Perguruan Tinggi Dalam Menghadapi Era Society 5.0
}

\author{
Higher Education's Strategy In Society 5.0 \\ Dimas Setiawan', Mei Lenawati \\ ${ }^{1,2}$ Sistem Informasi, Universitas PGRI Madiun, \\ ${ }^{1,2}$ Madiun, Indonesia \\ 1dimas.setiawan@unipma.ac.id, ${ }^{2}$ mei.lenawati@unipma.ac.id
}

\begin{abstract}
Abstrak-Perkembangan teknologi sistem informasi berkembang cukup pesat sehingga berdampak pada bermunculannya trend dari Revousi Industri 4.0 dan Society 5.0. Perguruan Tinggi merupakan salah satu Lembaga yang berkontribusi dalam kegiatan pendidikan di Indonesia tentunya harus mampu beradaptasi dalam menghadapi beberapa trend yang berkembang tak terkecuali trend Society 5.0. Upaya yang bisa dilakukan adalah memahami peran serta strategi yang perlu dilakukan perguruan tinggi dalam menghadapi era Society 5.0, dengan melakukan studi literatur mengenai Konsep Society 5.0 dan proses analisa data menggunakan metode analisa TOWS. Dari hasil analisa data dihasilkan Strategi yang bisa diambil oleh perguruan tinggi diantaranya dengan melakukan peningkatan produktifitas di bidang penelitian, pengabdian, serta riset berbasis inovasi yang mengarah pada terbentuknya konsep Smart City/ Smart Campus. Memperkuat kerja sama baik antar perguruan tinggi baik tingkat nasional maupun internasional. Mengadakan pelatihan kompetensi berskala nasional maupun internasional, demi mendukung jumlah profil lulusan yang sesuai dengan kebutuhan.
\end{abstract}

Kata kunci-Analisa TOWS, SDGs, Society 5.0, Perguruan tinggi, Revolusi Industri 4.0

\begin{abstract}
The development of information system technology is growing rapidly so that it has an impact on the emergence of trends from Industry 4.0 and Society 5.0 Higher Education is one of the Institutions that contribute to educational activities in Indonesia, of course, must be able to adapt in the face of several trends that are developing, including the 5.0 Society trend. The effort that can be done is to understand the role and strategies that need to be done by universities in facing the era of Society 5.0, by conducting a literature study on the Concept of Society 5.0 and the process of data analysis using the TOWS analysis method. The results of the analysis strategies that can be taken by higher education institutions were increased productivity in the fields of research of Smart Cities / Smart Campus. increase the cooperation between universities and put on competency training in multilevel national or international to support the graduates.
\end{abstract}

Keywords-Industry 4.0, Higher Education, SDGs, Society 5.0, TOWS Analyze

\section{Pendahuluan}

Pada tanggal 25 September 2015, Indonesia sebagai salah satu negara yang ikut berpartisipasi dalam Kegiatan Perserikatan Bangsa-Bangsa (PBB) melakukan kesepakatan bersama demi tercapainya tujuan pembangunan bekelanjutan (Sustainable Development Goals / SDGs). Hal ini ditandai dengan adanya Perpres SDGs Nomor 59 Tahun 2017 tentang pelaksanaan pencapaian tujuan pembangunan berkelanjutan yang terfokus di bidang lingkungan, sosial dan ekonomi.

Adanya pembangunan berkelanjutan ini beriringan dengan perkembangan dari teknologi dan sistem informasi yang berdampak pada terbentuknya Revolusi Industri 4.0, dimana di era ini terdapat perubahan dimana para pelaku industri dari berbagai kalangan baik pemerintahan maupun non pemerintahan mulai berlomba-lomba memanfaatkan penggunaan teknologi dan sistem informasi dalam proses bisnis. Hal ini ditandai dengan adanya beberapa peraturan tentang Sistem Pemerintahan berbasis Elektronik (SPBE), diantaranya Peraturan Menteri Pendayagunaan Aparatur Negara dan Reformasi Birokrasi Republik Indonesia No. 5 tahun 2018 tentang pedoman evaluasi sistem pemerintahan berbasis Elektronik, dan gerakan menuju 100 Smart city yang diprakarsai oleh KOMINFO, KEMENDAGRI, Kementrian PUPR, dan Bappenas [1]

Perkembangan teknologi dan sistem informasi saat ini berkembang cukup pesat dan arah pembangunan indonesia mulai mengarah 
kepada pengembangan kota cerdas (Smart City). [2] Upaya pengembangan smart city ini beriringan dengan perkembangan society 4.0 dimana terdapat perubahan pola perilaku masyarakat yang mengoptimalkan penggunaan Teknologi dan sistem informasi dan teknologi internet untuk mengakses segala bentuk informasi dan transaksi.

Namun Saat ini perkembangan dan pengimplementasian revolusi Revolusi Industri 4.0 dan society 4.0 di indonesia saat ini masih belum berjalan secara maksimal. Sebagai contoh di bidang industri, salah satunya muncul "Paradoks IT" dimana banyak perusahaan berlomba-lomba mengembangkan teknologi dan sistem informasi dengan biaya yang mahal namun belum efektif dalam mencapai tujuan. Di bidang society 4.0 masih minimnya wawasan masyarakat tentang literasi digital dalam penggunaan teknologi dan internet secara sehat dan positif.

secara umum perkembangan Revolusi Industri 4.0 dan society 4.0 di Indonesia dapat dikatakan belum terimplementasi secara sempurna, Namun konsep tentang Society 5.0 sudah terlebih dahulu diperkenalkan oleh jepang kepada dunia. Society 5.0 sendiri merupakan sebuah konsep dimana pengembangan Internet of Things, Big data, dan Artifical Intelligence diorientasikan untuk kehidupan manusia yang lebih baik, berbeda dengan konsep di Revolusi industri 4.0 dimana teknologi yang dikembangkan berorientasi pada produktifitas proses bisnis.

Adanya trend Society 5.0 menimbulkan dampak secara tidak langsung dimana Indonesia sebagai negara berkembang berhak untuk berperan secara aktif dalam mempersiapkan trend Society 5.0 kedepannya. Perguruan Tinggi merupakan salah satu Lembaga yang berkontribusi dalam kegiatan pendidikan di Indonesia tentunya harus mampu beradaptasi dalam menghadapi beberapa trend yang berkembang tak terkecuali trend Society 5.0. Universitas PGRI Madiun merupakan salah satu perguruan tinggi di kota madiun, yang memiliki visi menghasilkan lulusan yang cerdas, berdaya saing, dan memiliki kemampuan berwirausaha, berhak untuk andil dan berpartisipasi mendukung terciptanya lingkungan smart city.[3] dimulai dari mengikuti karateristik dari trend teknologi pendidikan yang mengarah pada penggunaan teknologi pembelajaran berbasis Online, mobile dan multimedia.[4]

Berdasarkan permalahan diatas, Salah satu upaya yang bisa dilakukan adalah memahami peran serta strategi yang perlu dilakukan perguruan tinggi dalam menghadapi era Society 5.0, dengan melakukan studi literatur mengenai Konsep Society 5.0 dan proses analisa data menggunakan metode analisa TOWS diharapan dapat menemukan peran serta strategi yang bisa dijadikan sebagai referensi kebijakan bagi perguruan tinggi dalam menghadapi tantangan di era Revolusi Industri 4.0 saat ini dan Society 5.0 kedepannya. Selain itu diperlukan komparasi keterkaitan anatra society 5.0 dengan Revolusi industri 4.0 dan SDGs sebagai data tambahan dalam menyusun peran dan strategi perguruan tinggi.

\section{LANDASAN TEORI}

\section{Revolusi Industri 4.0}

Menurut Davies (2015), Kinzel (2016), T.Pfeiffer, (2016) istilah industri 4.0 resmi dipublikasikan pada sebuah acara "Hannover Fair" di Jerman tahun 2012 sebagai bagian dari "Proyek masa depan" yang dibuat oleh "Germany's High-Tech Strategy 2020”. Dan Karakteristik model dari Industri 4.0 merupakan kombinasi dari beberapa perkembangan teknologi terbaru seperti sistem siber fisik, teknologi informasi dan komunikasi, jaringan komunikasi, big data dan cloud computing, pemodelan, virtualisasi, simulasi serta peralatan yang dikembangkan untuk kemudahan interaksi manusia dengan komputer [1]

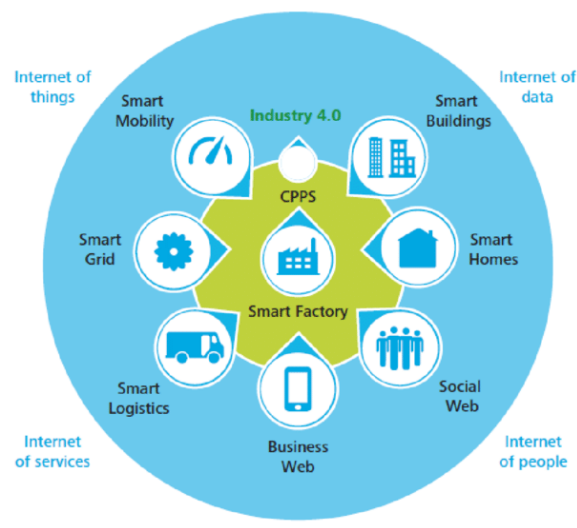

Gambar 1. Lingkungan Industri 4.0 [5] 


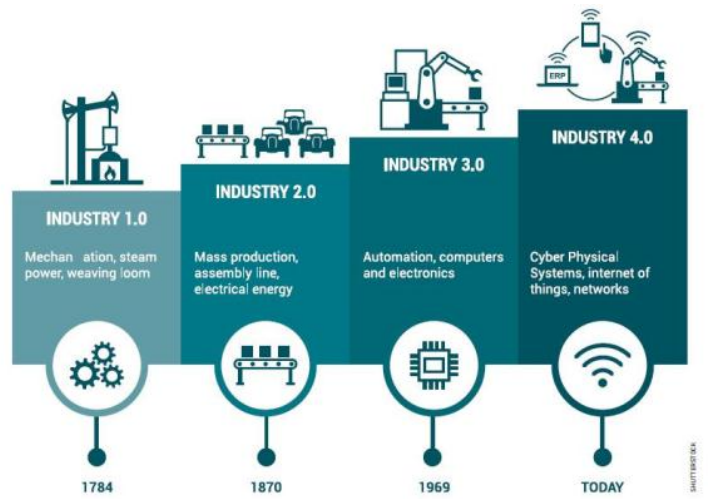

Gambar 2. Ilustrasi

perkembangan Industri 4.0

Berdasarakan karakteristik dan ilustrasi diatas dapat disimpulkan bahwa era Indstri 4.0 merupakan Era dimana Industri yang berkembang mengoptimalkan penggunaan teknologi informasi dan komunikasi seperti sistem informasi, Internet dan jaringan untuk meningkatkan kinerja serta produktifitas di perusahaan.

\section{Society 5.0}

Secara history Society 5.0 sendiri merupakan sebuah konsep yang diusulkan oleh keidanren yang merupakan sebuah federasi bisnis jepang. Menurut Dr. Masahide Okamoto (2019) Society 5.0 merupakan representasi bentuk sejarah perkembangan masyarakat ke-5. Dimana secara kronolgis perkembangannya dimuai dari era dimana masyarakat memiliki pola untuk melakukan pemburuan (Society 1.0), berlanjut ke era pertanian (society 2.0 ), industri (Society 3.0), dan informasi (4.0).

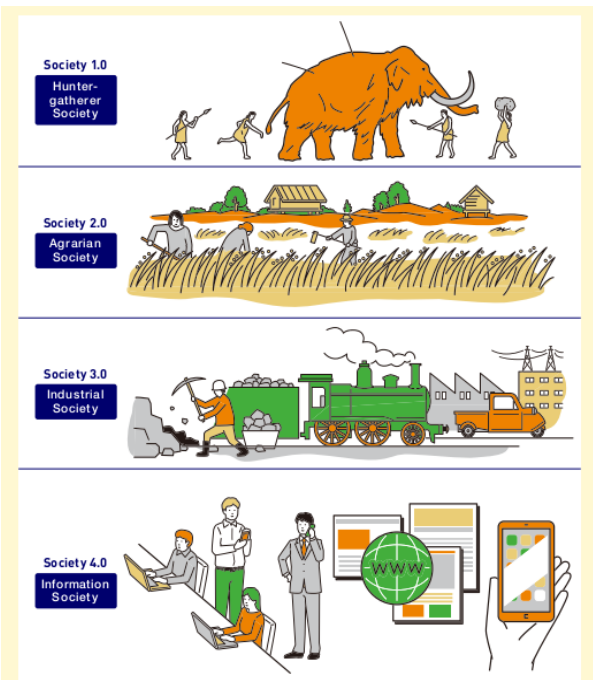

Gambar 3. Illustrasi perkembangan society $4.0[6]$

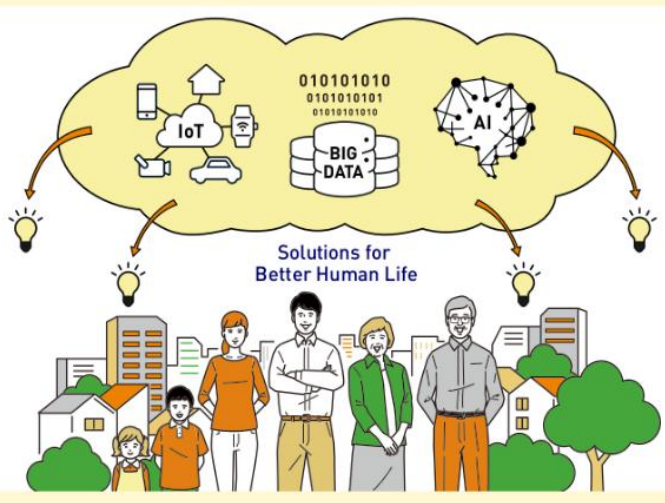

Gambar 4. Ilustrasi konsep society 5.0 [6]

Berdasarkan ilustrasi gambar 4 dan pembahasan diatas dapat disimpulkan bahwa Society 5.0 merupakan sebuah konsep yang dikembangkan demi terbentuknya masyarakat Super smart yang memiliki pola perilaku mengoptimalkan pemanfaatan Internet Of things, Big Data, dan Artificial Intelligence sebagai solusi untuk kehidupan masyarakat yang lebih baik.

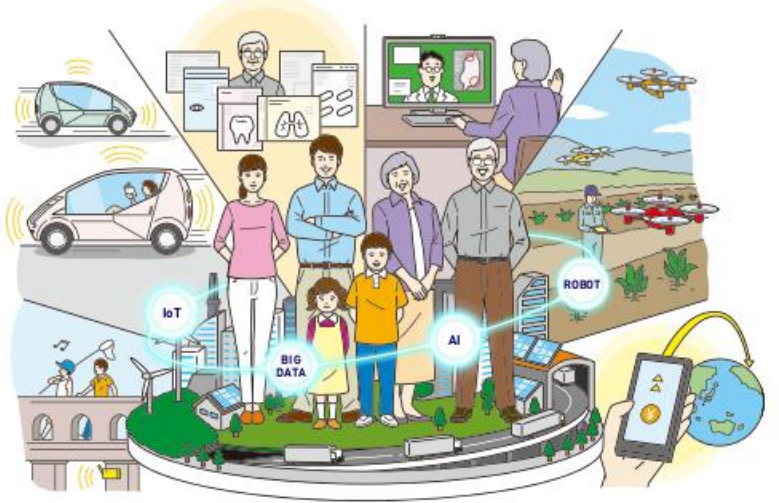

Gambar 5. Ilustrasi implementasi society 5.0 (japan.Governance)

Implementasi dari Society 5.0 di jepang diilustrasikan dengan gambar 5 diatas dengan adanya beberapa teknologi teknologi drone serta artifical intelligence untuk pengiriman barang, sistem perawatan medis yang terintegrasi, autonomus vehicles yang berfungsi untuk mengkondisikan kendaraan tanpa awak. Adanya robot dan sensor yang yang dimaksimalkan untuk sistem inspeksi dan pemeliharaan infrastruktur.

\section{SDGs (Sustainable Develompent Goals)}

SDgs (Sustainable Develompent Goals) atau tujuan pembangunan berkelanjutan merupakan 
sebuah kesepakatan pembangunan global yang disepakati oleh kurang lebih 193 kepala negara pada tanggal 25 september 2015 di Markas Besar PBB termasuk indonesia. Kesepakatan pembangunan global ini menghasilkan 17 tujuan yang dapat dilihat pada gambar 6 dibawah ini :

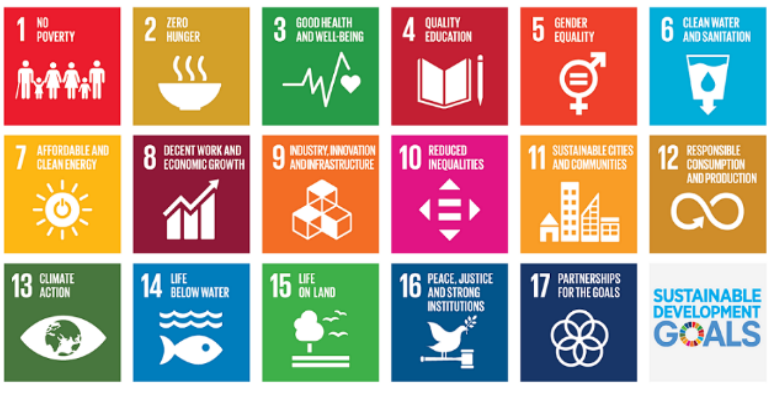

Gambar 6. 17 Tujuan SDGs

pencapaian tujuan pembangunan berkelanjutan diatas pada prinsipnya memiliki fokus di bidang lingkungan, sosial dan ekonomi.

\section{METODE}

Adapun Bahan yang diperlukan dalam penelitian ini adalah literasi pustaka mengenai konsep dan keilmuan yang membahas mengenai Society 5.0 dan analisa TWOS, untuk tambahan diperlukan kajian pustaka mengenai SDGs (Sustainable Development Goals) dan
Revolusi Industri 4.0 hal ini diperlukan untuk mengetahui keterkaitan serta korelasi diantara bahan kajian.

Adapun terkait Metode yang digunakan, terdapat beberapa tahapan yang dapat dilakukan

1. Identifikasi Permasalahan \& Perumusan Masalah

2. Penelusuran Pustaka / Pencarian Literatur

3. Pengumpulan Data

4. Pengolahan Data/ Analisa Data

5. Penyimpulan Hasil.

\section{HASIL}

Berdasarkan hasil dari uraian dari latar belakang, diatas terdapat beberapa pertanyaan penelitian yang merupakan hasil dari identifikasi dan perumusan masalah :

1. Bagaimanakah Hubungan antara Society 5.0, dengan Revolusi Industri 4.0 dan SDGs ?

2. Bagaimanakah Peran dan Strategi Perguruan tinggi dalam menghadapi era Society 5.0 menggunakan analisa TOWS ?

\section{Hubungan antara Society 5.0, dengan} Revolusi Industri 4.0

Setelah melakukan peninjuan pustaka terkait SDGs, Revolusi Industri 4.0 dan Society 5.0. Langkah selanjutnya melihat hubungan diantara masing masing pokok bahasan.

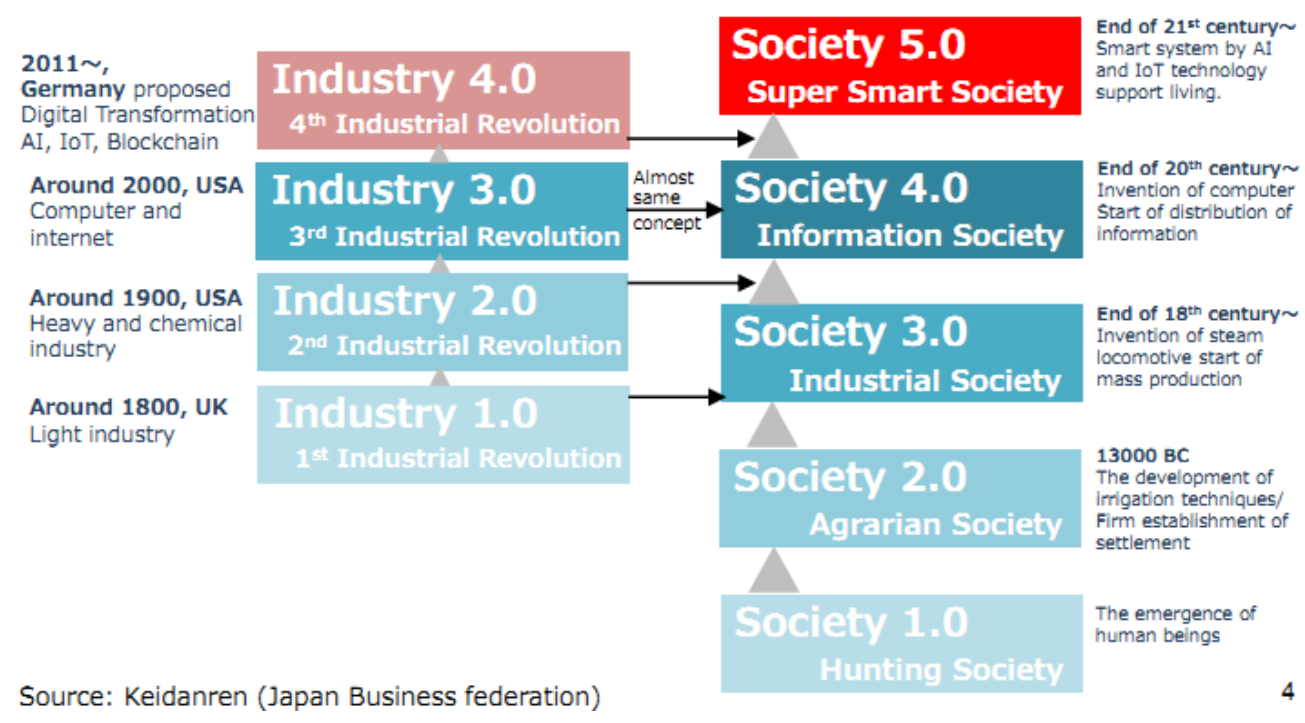

Gambar 7. Korelasi antara konsep Society 5.0 dan konsep Industry 4.0 [7]

Berdasarkan gambar 7 diatas dapat dilihat hubungan dan korelasi antara Industry 4.0 dan Society 5.0 dimana konsentrasi dari industry
4.0 dan Society 5.0 memiliki kesamaan yaitu terfokus pada teknologi yang dikembangkan secara Digitalisasi serta memanfaatkan 
Artificial Intelligence, Internet of Things, dan Big data untuk proses transaksi dan dan penyebaran informasi, serta Blockchain sebagai sistem keamanannya.

Hanya saja yang membedakan disini adalah orientasi dari konsep Industry 4.0 dan Society 5.0 dimana untuk Revolusi Industry 4.02 terfokus pengoptimalan teknologi dan sistem informasi untuk keperluan produktifitas dan proses bisnis sebagai contoh adanya sistem informasi Enterprise di berbagai perusahaan. Sedangkan pada konsep Society 5.0, pengoptimalan teknologi dikembangkan untuk kebutuhan kemanusiaan sebagai contoh sistem perawatan medis yang terintegrasi.

\section{- Hubungan antara Society 5.0, dengan SDGs}

Untuk melihat hubungan antara society 5.0 dengan SDGs, dapat diamati melalui ekosistem yang ada di society 5.0

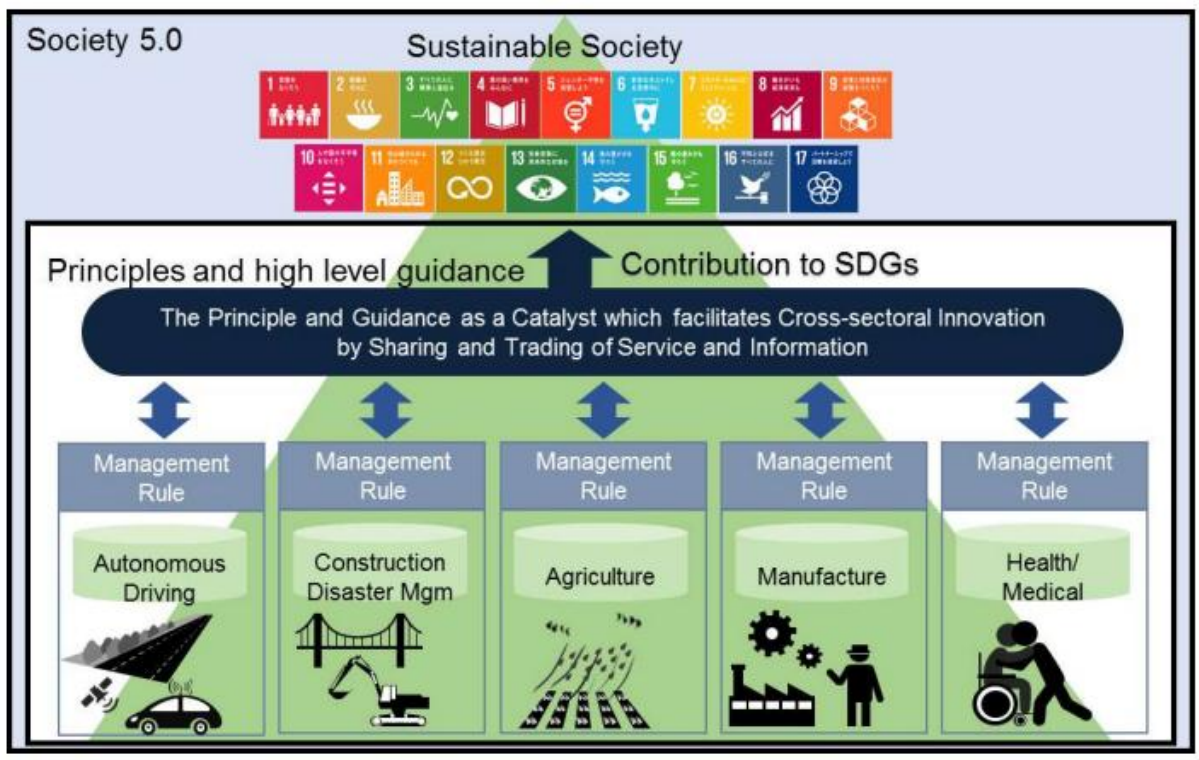

Gambar 8. Ekosistem Society 5.0 [7]

Berdasarkan gambar ekosistem society 5.0 diatas, dapat dilihat bahwa bentuk konsep Autonomus Driving, Construction Disaster management, Agriculture, Manufacture, serta Health/medical yang dikembangkan di Society 5.0 memiliki aturan manajemen yang secara prinsip mengarah pada tujuan pembangunan berkelanjutan (SDGs). Sebagai contoh salah satu konsep sistem perawatan medis yang terintegrasi nantinya dapat dikorelasikan dengan tujuan SDGs ke-3 yaitu Memastikan kehidupan yang sehat dan mendukung kesejahteraan bagi semua untuk semua usia.

\section{Hasil analisa TOWS dari Perguruan Tinggi terhadap era Society 5.0}

Analisis TOWS merupakan analisa yang digunakan membandingkan antara faktor eksternal peluang (opportunity) dan ancaman (threats) dengan faktor internal kekuatan (strenght) dan kelemahan (weakness). Berikut adalah hasil analisa TOWS dari perguruan tinggi yang ada di Indonesia.

\section{Threatment (Ancaman)}

1. Munculnya Era Masyarakat Ekonomi Asean dimana berdampak pada banyaknya tenaga kerja asing yang masuk ke indonesia.

2. Banyaknya perguruan tinggi di luar negeri yang memiliki daya saing yang lebih baik dari berbagai sisi baik sarana, prasarana, dan manajemen perguruan tinggi.

\section{Opportunity (Peluang)}

1. Indonesia merupakan salah satu negara yang memiliki hak untuk mendukung tercapainya Pembangunan berkelanjutan (SDGs)

2. Perguruan tinggi di indonesia merupakan tempat bertumbuhnya Inovasi, dan teknologi berbasis riset/penelitian dan pengabdian masyarakat.

3. Mulai berkembangnya trend revousi Industri yang ditandai dengan adanya Konsep Smart City yang didalamnya terdapat Smart Campus. 


\section{Weakness (Kelemahan)}

Kualitas masing-masing perguruan tinggi

di indonesia yang heterogen.

1. Perguruan tinggi di indonesia yang terakreditasi hanya sejumlah 2.149 [8]

2. Banyaknya jumlah lulusan yang belum memenuhi kualifikasi kebutuhan di dunia Industri

\section{Strength (Kekuatan)}

1. Jumlah perguruan tinggi di indonesia yang cukup banyak mencapai 4.717 yang terdiri dari Universitas, Akademi, Politeknik, Akademi Komunitas, Sekolah tinggi, Institut. [9]

2. Jumlah mahasiswa yang mencapai 6.994.546 dan kemungkinan bertambah tiap tahunnya. [10]

3. Prestasi dan Inovasi perguruan tinggi yang dimiliki perguruan tinggi di berbagai perlombaan di tingkat internasional.

Adapun Strategi yang bisa dilakukan berdasarkan analisa TWOS :

Tabel 1 Matriks Analisa TOWS

\section{STRENGTH (S)}

Jumlah perguruan tinggi di indonesia yang cukup banyak mencapai 4.717 yang terdiri dari Universitas, Akademi, Politeknik, Akademi Komunitas, Sekolah tinggi, Institut.

Jumlah mahasiswa yang mencapai

\section{IFAS / EFAS}

\begin{abstract}
6.994.546 dan kemungkinan bertambah
\end{abstract} tiap tahunnya.

Prestasi dan Inovasi perguruan tinggi

yang dimiliki perguruan tinggi di

berbagai perlombaan di tingkat internasional.

\footnotetext{
OPPORTUNITIES (O)

Indonesia merupakan salah satu negara yang memiliki hak untuk mendukung tercapainya Pembangunan berkelanjutan (SDGs) Perguruan tinggi di indonesia merupakan tempat bertumbuhnya Inovasi, dan teknologi berbasis riset/penelitian dan pengabdian masyarakat. Mulai berkembangnya trend revousi Industri yang ditandai dengan adanya Konsep Smart City yang didalamnya terdapat Smart Campus.
}

\section{WEAKNESS (W)}

Kualitas masing-masing perguruan tinggi di indonesia yang heterogen. Perguruan tinggi di indonesia yang terakreditasi hanya sejumlah 2.149 Banyaknya jumlah lulusan yang belum memenuhi kualifikasi kebutuhan di dunia Industri

\section{STRATEGI SO \\ Ciptakan strategi yang menggunakan kekuatan untuk memanfaatkan peluang}

Peningkatkan produktifitas penelitian dan pengabdian masyarakat yang mengarah pada konsep Smart City / Smart Campus.

Peningkatan Inovasi yang mengarah ke pengembangan konsep Smart City / Smart Campus.

Memaksimalkan kualitas kerja sama antar perguruan tinggi di bidang riset penelitian dan pengabdian masyarakat.

\section{STRATEGI WO \\ Ciptakan strategi yang meminimalkan kelemahan untuk memanfaatkan peluang}

Peningkatan kerja sama antar perguruan tinggi dalam negeri. Peningkatan kualitas mutu manajemen perguruan tinggi serta produktifitas tri dharma perguruan tinggi dengan mengadakan studi banding.

Pengadaan Workshop atau literasi mengenai trend perkembangan revolusi industri 4.0 serta kebijakan pembangunan secara global (SDGs) Penguatan sertifikasi kompetensi bagi lulusan perguruan tinggi.

\section{STRATEGI WT \\ Ciptakan strategi yang meminimalkan kelemahan dan menghindari ancaman}

Peningkatkan kualitas lulusan dari pendidikan tinggi, dengan membekali pelatihan dan sertifikasi kompetensi baik tingkat lokal maupun internasional. Peningkatan produktifitas mahasiswa di bidang kegiatan yang mengarah pada kreatifitas dan inovasi baik secara tertulis maupun terapan
Peningkatan kerja sama dengan perguruan tinggi luar negeri. Pengadaan pelatihan kompetensi bersakala internasional Peningkatan kemampuan komunikasi menggunakan bahasa internasional. prasarana, dan manajemen perguruan tinggi. 
V. Kesimpulan

1. Konsep Industry 4.0 dan Society 5.0 memiliki persamaan yaitu terfokus pada pengembangan dan pemanfaatan teknologi seperti Internet Of things (IOT), Artificial Intelligence, dan Big Data.

2. Konsep Industry 4.0 dan Society 5.0 memiliki Perbedaan dimana orientasi industry 4.0 terfokus pada pengembangan dan pemanfaatan teknologi untuk keperluan produktifitas dan proses bisnis, Sedangkan Society 5.0 berorientasi pada pengembangan dan pemanfaatan teknologi untuk kehidupan masyarakat yang lebih baik.

3. Realisasi konsep Masyarakat 5.0 mengarah pada pencapaian Tujuan Pembangunan Berkelanjutan (SDGs).

4. Strategi yang bisa diambil oleh perguruan tinggi dapat dilakukan dengan melakukan peningkatan produktifitas di bidang penelitian, pengabdian, serta riset berbasis inovasi yang mengarah pada terbentuknya konsep Smart City/ Smart Campus.

5. Memperkuat kerja sama baik antar perguruan tinggi baik tingkat nasional maupun internasional.

6. Mengadakan pelatihan kompetensi berskala nasional maupun internasional, demi mendukung jumlah profil lulusan yang sesuai dengan kebutuhan.

\section{DAFTAR PUSTAKA}

[1] R. Fauzan, "Karakteristik Model dan Analisa Peluang-Tantangan Industri 4.0," J. Tek. Inform. Politek. Hasnur, vol. 4, no. April 2018, pp. 1-11, 2018.

[2] D. Setiawan, "Analisis Dan Perancangan Sistem Informasi LENTERA Untuk Membentuk ' Smart Society ' Di Lingkungan Kampus Menggunakan Metode OOAD ( Studi Kasus : Universitas PGRI Madiun ),” pp. 155159, 2019.

[3] D. Setiawan, "PERSPEKTIF ELEARNING DOSEN PROGRAM STUDI SISTEM INFROMASI UNIPMA," Res. Comput. Inf. Syst. Technol. Manag., vol. 1, no. 2, pp. 1-6, 2018.
[4] D. Setiawan and H. A. M. Noordin Asnawi, "LECTURERS INFORMATICS ENGINEERING STUDY PROGRAM," no. Icons, pp. 1168-1173, 2017.

[5] S. Teitel and S. Teitel, "Manufacturing Industry," Technol. Ski. Zimbabwe's Manuf., pp. 18-25, 2000.

[6] Government of Japan, "Realizing Society 5.0," p. 5, 2018.

[7] M. Okamoto, "Standardization activities on 'Society 5.0' in Japan," Society 5.0 Standardization Promotion Committee," no. March, pp. 0-18, 2019.

[8] Ban PT, "Peringkat Akreditasi Institusi Per Provinsi," jakarta, 2019. [Online]. Available: www.banpt.or.id.

[9] Ristekdikti, "Grafik Jumlah Perguruan Tinggi," jakarta, 2019. [Online]. Available: https://forlap.ristekdikti.go.id/perguruanti nggi/homegraphpt.

[10] Ristekdikti, "Grafik Jumlah Mahasiswa Aktif Sesuai Kelompok Bidang," jakarta, 2019. [Online]. Available: https://forlap.ristekdikti.go.id/mahasiswa/ homegraphbidang. 